\title{
Anomalous Heat Flow in the Northwest Atlantic: A Case for Continued Hydrothermal Circulation in 80-M.Y. Crust
}

\author{
ROBERT W. EMBLEY \\ National Ocean Survey/NOAA, Rockville, Maryland 20852
}

\author{
Michael A. Hobart, Roger N. Anderson, ${ }^{1}$ and Dallas Abbott ${ }^{1}$ \\ Lamont-Doherty Geological Observatory of Columbia University, Palisades, New York 10964
}

\begin{abstract}
A detailed study of a $60 \times 150 \mathrm{~km}$ area at $60^{\circ} \mathrm{W}, 24^{\circ} \mathrm{N}$ at the eastern end of the Nares Abyssal Plain indicates that hydrothermal circulation is still active in the 80 m.y. B.P. oceanic crust. The 58 heat flow measurements made at five stations in the area have revealed (1) constant heat flow over the abyssal plain ( $\left.56 \mathrm{~mW} \mathrm{~m}^{-2}\right)$, (2) a cyclic heat flow over the abyssal hills (mean of $77 \mathrm{~mW} \mathrm{~m}^{-2}$ ), and (3) a large anomaly of $710 \mathrm{~mW} \mathrm{~m} \mathrm{~m}^{-2}$ over one of several small domes which protrude from the abyssal plain. The domes are $0.5-1.0 \mathrm{~km}$ in diameter near the top and rise $50 \mathrm{~m}$ above the level of the abyssal plain. They are recognized from surface echo sounders by an abrupt disappearance in the abyssal plain subbottom reflectors, but on near-bottom pinger records they appear as steep-walled structures which are covered by $\sim 10 \mathrm{~m}$ of sediment (compared to $\sim 75 \mathrm{~m}$ on the surrounding abyssal hills). From analogy with active ridge crests, these features are probably small volcanoes. The heat flow anomaly over one of the domes is matched well by a finite element convection model with the following characteristics: (1) recharge at one basement outcrop and discharge at another, (2) $300 \mathrm{~m}$ of sediment fill between outcrops, and (3) permeabilities of $10^{-10} \mathrm{~cm}^{2}$ for basalt and $10^{-13} \mathrm{~cm}^{2}$ for sediment. In other words, we believe that there is very effective convective heat transfer within the crust and out of the relatively permeable, thinly sedimented basement dome, resulting in the local high heat flow. Overall, the results from the Nares survey vividly show the age independent muting effect of sediment on the surface manifestation of crustal convection. In our survey area the mode of heat transfer varies from purely conductive in the more thickly sedimented abyssal plain areas $(\sim 300 \mathrm{~m}$ sediment cover) to moderate amplitude convection pattern beneath the abyssal hills ( $\sim 75 \mathrm{~m}$ sediment cover) to a very large thermal anomaly over the small dome or 'chimneylike' structure $(\sim 10 \mathrm{~m}$ sediment cover). The domes are possibly active analogues to the presently inactive basement chimney drilled at DSDP site 417A.
\end{abstract}

\section{INTRODUCTION}

The results of oceanic heat flow studies published in the past 10 years have demonstrated the importance of hydrothermal convection in young oceanic crust [e.g., Talwani et al., 1971; Lister, 1971; Anderson et al., 1977]. The early work laid the ground for the spectacular discoveries of active hydrothermal vents on the medium spreading ridges of the Pacific [e.g., Corliss et al., 1979; RISE Project Group, 1980]. Comparison of observed versus measured heat flow also predict that hydrothermal circulation may continue in old crust, albeit at a diminishing rate [Anderson and Hobart, 1976; Anderson et al., 1977]. The rate and age at which the measured values merge with the values calculated for a uniformly cooling plate is dependent on variables such as the particular spreading center under consideration, sediment thickness, sediment lithology, and basement roughness [e.g., Anderson et al., 1977]. Two primary mechanisms have been suggested to explain the approach to conductive seafloor geothermal flux: sealing off of cracks in the basement rocks and capping by relatively impermeable sediments.

In 1976 a seismic survey in the eastern Nares abyssal plain (Figure 1) made in conjunction with a sediment physical properties study discovered a series of unusual domelike

\footnotetext{
${ }^{1}$ Also with the Department of Geological Sciences, Columbia University, New York, New York, 10027.
}

Copyright 1983 by the American Geophysical Union.

Paper number 2B1358.

0148-0227/83/002B-1358\$05.00 structures protruding from the eastern Nares Abyssal Plain. These domes vividly contrasted with the normal abyssal hills in the area in that they had no discernible return echo; they were recognized by a sharp cutoff in the abyssal plain subbottom reflectors (Figure 2). A multidisciplinary study was undertaken in 1978 which included coring, underway geophysics, and multipenetration heat flow studies. The results of the 1978 cruise are presented in this paper.

\section{Regional Setting}

The area under discussion is at the easternmost end of the Nares abyssal plain (Figure 1), where the distal abyssal plain sediments penetrate between low relief $(\sim 500 \mathrm{~m})$ abyssal hills. The underlying crust has been dated by magnetic anomalies at about $80 \mathrm{~m}$.y. [Pitman and Talwani, 1972].

The regional topography has two distinct trends which reflect the traces of minor fracture zones (NW-SE) and the remnants of old rift blocks (NE-SW). The continuity of anomalies 33 and 34 (Figure 1) implies that no major fracture zone passes through the survey area. Also, the survey area appears to lie on the 'smooth' side of the 'rough-smooth' basement character transition which Rabinowitz and Ludwig [1980] have identified between anomaly 33 and 34 (Figure 1). They suggest that the rough-smooth basement transition is the morphologic expression of the change from faster to slower spreading during the Late Cretaceous [Larson and Pitman, 1972]. If this is correct, the crust in the survey area was created during a period when the spreading rate was $50 \%$ greater than at present.

A summary of heat flow values plotted versus age for the 


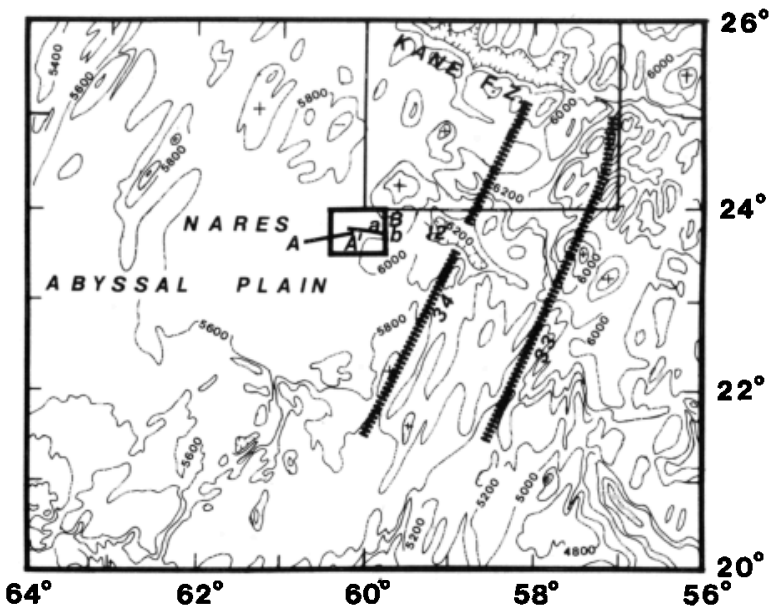

Fig. 1. Medium-scale regional bathymetry map (Navoceano Maps 9, 9a). The Nares survey is shown by the smaller box, while the area described by Rabinowitz and Ludwig [1980] is shown by the larger box. Magnetic anomalies 33 and 34 [after Rabinowitz and Ludwig, 1980] are shown by thick dashes. Locations of profile A$A^{\prime}-B$ (Figure 5) is shown.

Atlantic (Figure 3) shows that the measured mean heat flow approaches the theoretical cooling curve at 65-70 m.y. and thereafter follows it rather closely. The mean heat flow for the survey area $(80 \mathrm{~m} . \mathrm{y}$. B.P.) predicted by this curve is 60

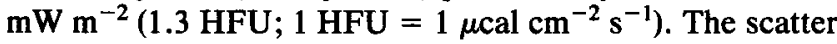
is very large for young crust $(<25 \mathrm{~m} . \mathrm{y}$. B.P. in the case of the Atlantic); it rapidly decreases in $25-75 \mathrm{~m} . \mathrm{y}$. B.P. crust, increases somewhat in the 75-110 m.y. B.P. crust, then decreases and remains very small for the $110 \mathrm{~m} . \mathrm{y}$. B.P. crust. The moderate increase in scatter for 75-110 m.y. B.P. crust correlates with the period of rapid spreading proposed by Larson and Pitman [1972].

\section{Description of Survey Area}

\section{Structure and Sediments}

The bathymetry of the detailed survey area (Figure 4) was constructed using the satellite-navigated tracklines of three CONRAD cruises. Most of the area is abyssal plain, which gently slopes from west $(5920 \mathrm{~m})$ to east $(5945 \mathrm{~m})$. The abyssal hills are lineated in a $\mathrm{N} 20^{\circ} \mathrm{E}$ azimuth and are of low $(100-200 \mathrm{~m})$ to moderate relief $(500-600 \mathrm{~m})$. The airgun seismic records (Figure 5) reveal that the gentler abyssal hills are covered with about $300 \mathrm{~m}$ of ponded abyssal plain sediments. Below the abyssal plain turbidites, the lowermiddle Eocene horizon $A^{c}$ [Tucholke and Mountain, 1979] is present. The part of profile A-B (Figure 5) made just west of the survey area shows a thick sequence of Eocene turbidites derived from the North American margin.

The nature of the surficial sediments in the survey region is known from eight cores taken during the two LamontDoherty Geological Observatory cruises (Figure 6). Six of the cores (RC19-27-30, RC20-12-13) penetrated abyssal plain sediments; core $\mathrm{RC20-14}$ was taken on one of the small transparent domes and core RC20-15 was taken on one of the low-relief abyssal hills.

The abyssal plain cores consist mostly of homogeneous gray clays with uniform physical properties [Tucholke, 1980]. A small change in the velocity at about $8 \mathrm{~m}$ correlates

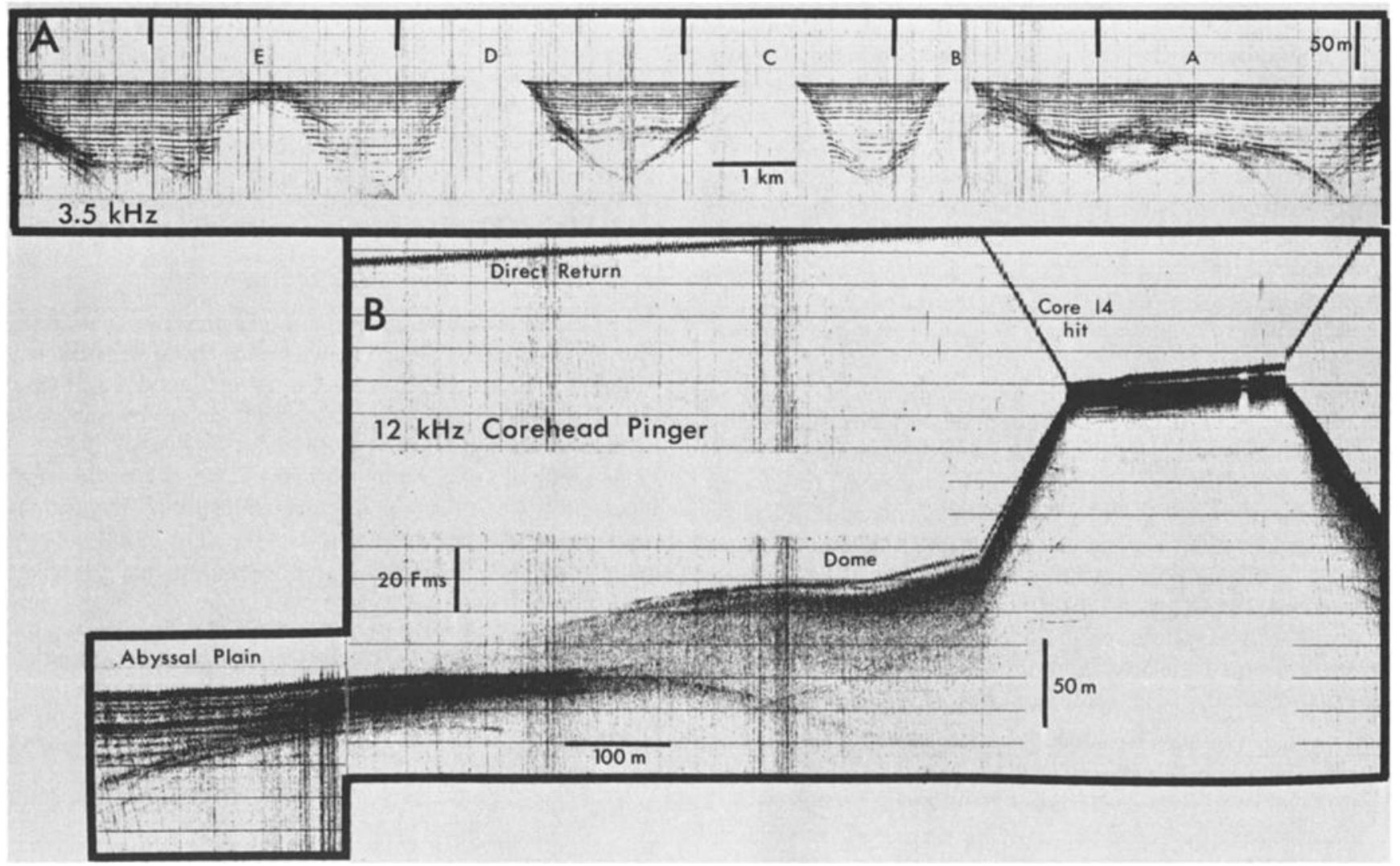

Fig. 2. (top) Prestation (Core 14, Figure 6) survey (3.5 kHz PDR) for dome on eastern Nares abyssal plain survey was made by turning ship on tight reverse course (bars) as soon as dome was crossed. (bottom) 12 -kHz pinger record over flank and top of dome. The pinger was mounted in a hole in corehead. Actual profile ends just to left of 50-m mark. 


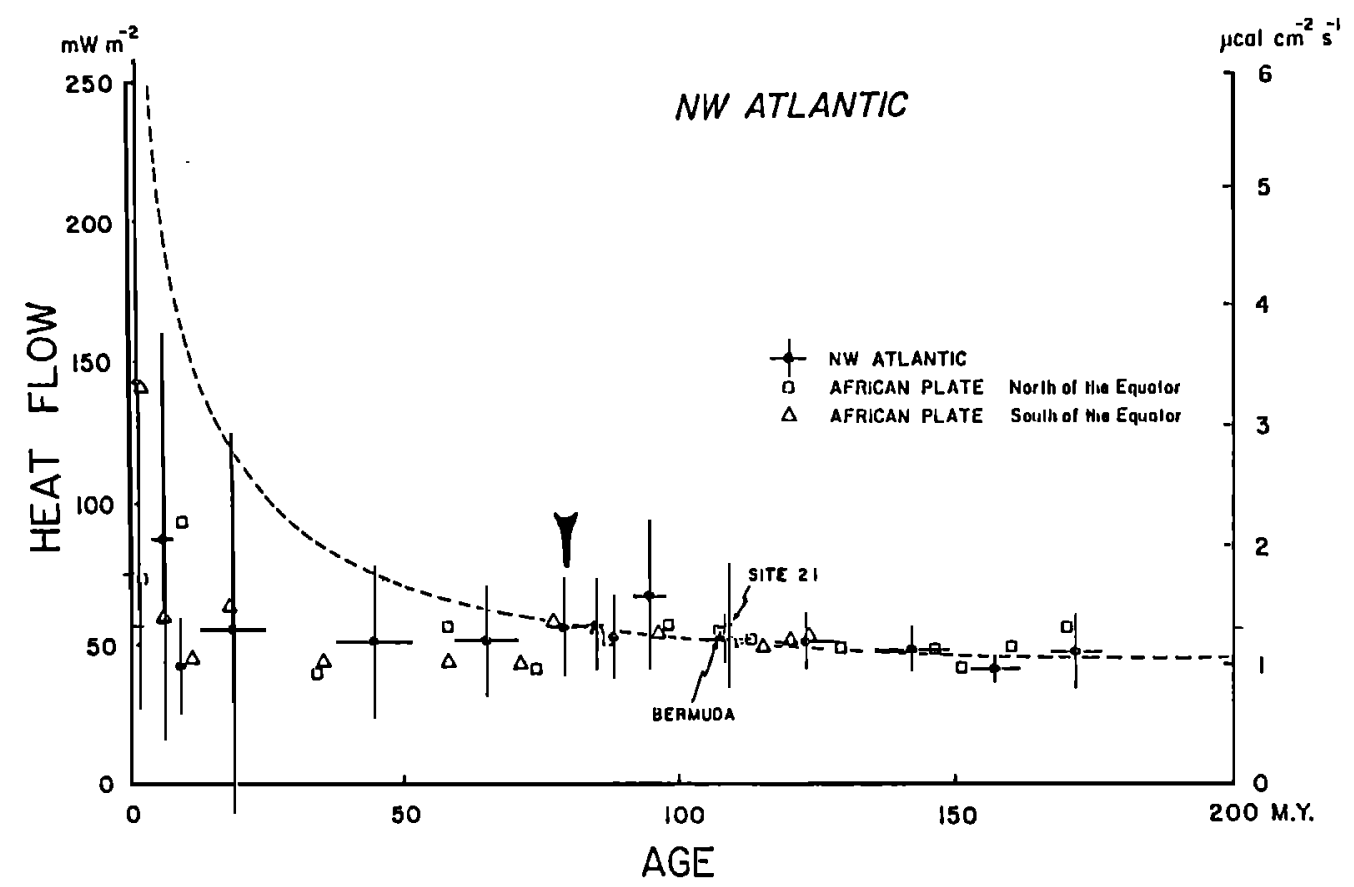

Fig. 3. Heat flow versus age for Northwest Atlantic. Crosses are total ranges of ages and heat flow. Dashed line is theoretical curve for cooling lithospheric plate [Anderson and Skilbeck, 1982]. Heat flow units are milliwatts per square meter. Arrow denotes relative position of Nares survey.

with a subbottom reflector observed on the $3.5-\mathrm{kHz}$ records throughout the area. These cores contain few if any silt partings; the gray clays represent distal turbidites derived ultimately from North America. A few small layers $(\sim 10 \mathrm{~cm}$ thick) show deformation structures and could represent locally derived mass flow deposits.

Core RC20-15, taken on a low-relief hill in the southern part of the survey area, consists of $2 \mathrm{~m}$ of brown pelagic clay

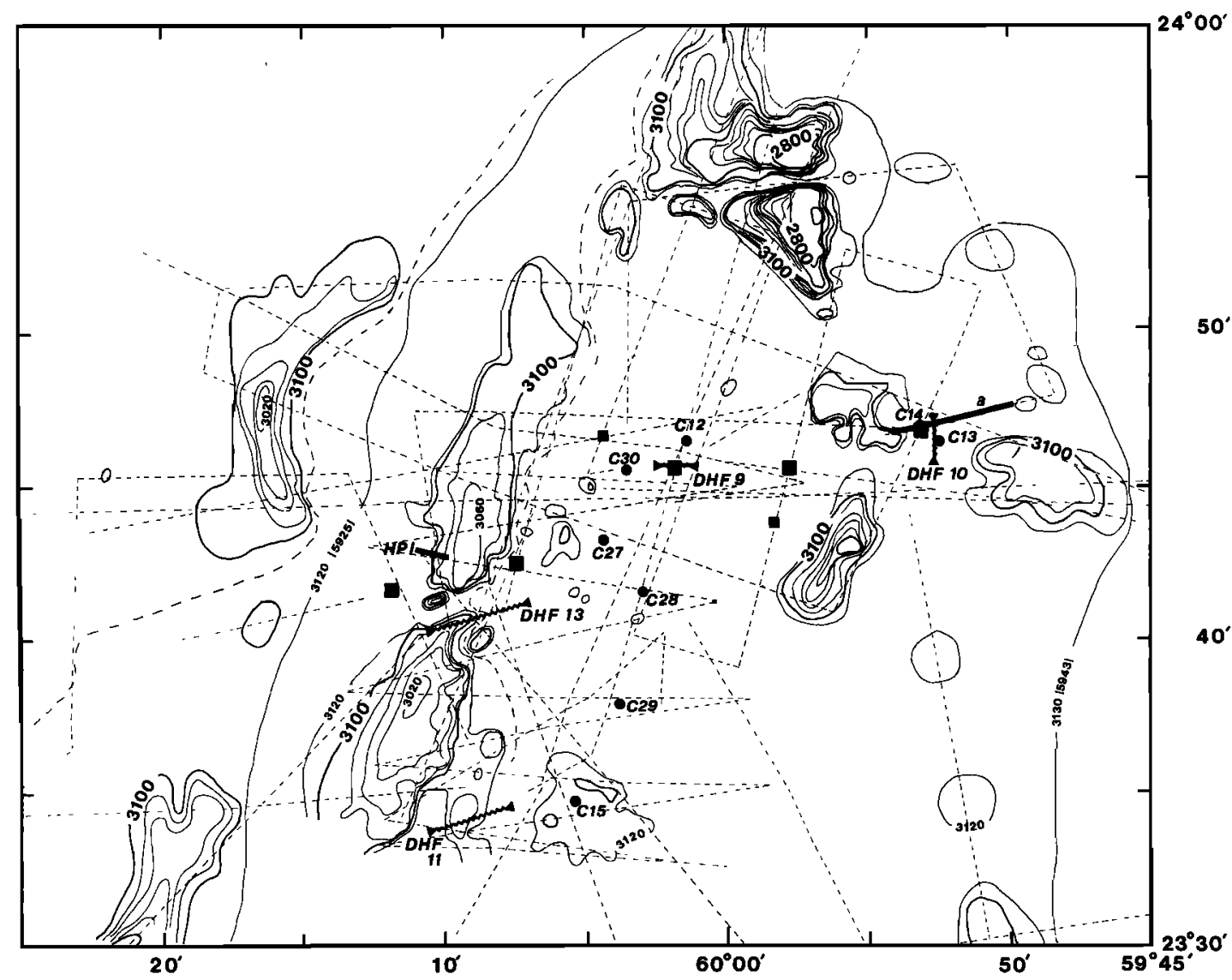

Fig. 4. Bathymetry of survey area. Contours in fathoms and corrected meters. Contour interval $5 \mathrm{fms}$ over abyssal plain and 20 fms over abyssal hills. Dashed lines are tracks of RC17-01, RC19-06, RC19-07, and RC21-16. Boxes denote some structures. Dots show core locations (RC19-27-30 and RC21-12-15) and wiggly lines with triangles show location of digital heat flow profiles (e.g., DHF9). 


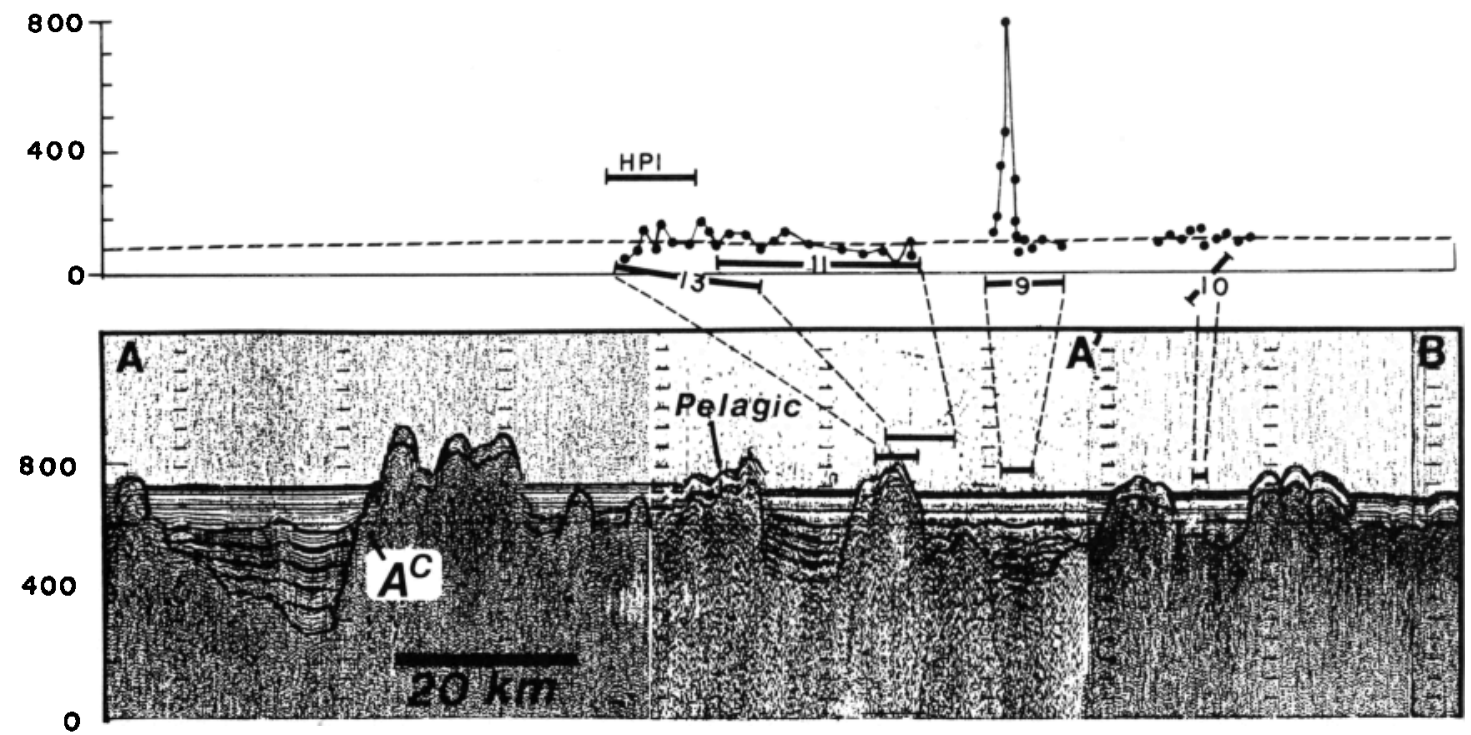

Fig. 5 Airgun seismic profile across eastern Nares abyssal plain in west to east direction. Major acoustic boundaries have been enhanced. Location shown on Figure 1 . Horizon $A^{c}$ may also be present in low areas between hills on eastern end of profile. Heat flow profiles $(9,10,11,13)$ shown above relative with locations projected onto seismic profile. For exact locations, see Table 1 and Figure 4.

overlain by $6 \mathrm{~m}$ of alternating clay and silt turbidites. These coarser layers are probably deposits from occasional massive turbid clouds which were sufficiently energetic to deposit on the hill [Abbott and Embley, 1982]. The $6 \mathrm{~m}$ containing the silt layers could be equivalent to the $100 \mathrm{~m}$ of post-Eocene sediments in the abyssal plain.

\section{Heat Flow}

The primary goals of the heat flow program were (1) to better characterize the regional heat flow in particular to establish the topographic influence and (2) to obtain a detailed heat flow profile over a dome structure. A multipenetration digital heat flow instrument was used for the profiles. (See the introduction to this issue for a description of the instrument.) The Lamont-Doherty Geological Observatory model includes a 5-m probe with the electronic package mounted in a $1500 \mathrm{lb}$ corehead. The data was telemetered back to the ship through a pulse time interval technique using a modified 12-kHz Benthos pinger. Four profiles (9, 10,11 , and 13) were made in the primary survey area (Figures 1 and 4) and a fifth profile (12) about $100 \mathrm{~km}$ to the east (Figure 1). A total of 58 successful measurements were made (Figure 1 and Table 1). The bottom morphology in which the measurements were taken was recorded either by the telemetering $12-\mathrm{kHz}$ pinger or by a $3.5-\mathrm{kHz}$ pinger mounted on the wire above the corehead. The latter arrangement was found to be preferable because of the weak downward signal strength from the inverted pinger head.

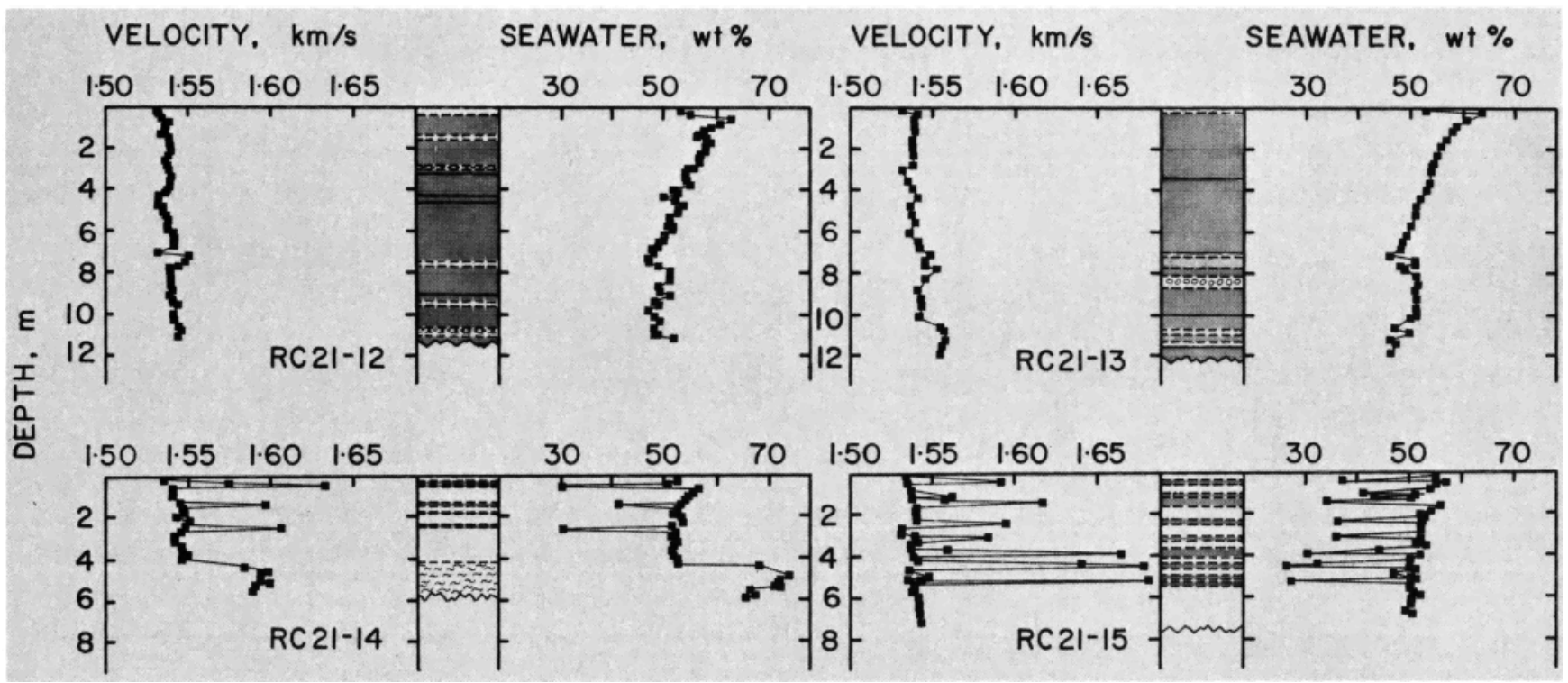

Fig. 6. Water content, seismic velocity, and stratigraphic section plotted against depth for cores RC21-12, 13, 14, and 15. Turbidite layers are designated by gray, bioturbated moderate brown clay by blanks, pink hydrothermal clay mixed with manganese by wavy lines, black layers by black lines, contacts between two layers by dashed lines, and possible slumped layers by circles. Two turbulently mixed layers too thin to designate occur at $289-298 \mathrm{~cm}$ and $1072-$ $1090 \mathrm{~cm}$ in RC21-12. 
TABLE 1. R. D. Conrad 21-16 Heat Flow Stations

\begin{tabular}{|c|c|c|c|c|c|c|c|c|c|}
\hline Station & $\begin{array}{l}\text { Latitude, } \\
\text { N }\end{array}$ & $\begin{array}{l}\text { Longitude, } \\
W\end{array}$ & $\begin{array}{l}\text { Depth, } \\
\text { m }\end{array}$ & $\begin{array}{c}\text { Penetration, } \\
\text { m }\end{array}$ & $N_{P}$ & $\begin{array}{l}\text { GRD, } \\
\mathrm{mK} / \mathrm{m}\end{array}$ & $N_{K}$ & $\begin{array}{c}K \\
\mathrm{~W} / \mathrm{mK}\end{array}$ & $\underset{\mathrm{mW} / \mathrm{m}^{2}}{Q,}$ \\
\hline \multicolumn{10}{|l|}{$\overline{D H F}$} \\
\hline $9 A$ & $23^{\circ} 45.4^{\prime}$ & $60^{\circ} 03.0^{\prime}$ & 5933 & 6.0 & 5 & 128 & & $(0.87)$ & 111 \\
\hline $9 B$ & $23^{\circ} 45.4^{\prime}$ & $60^{\circ} 02.9^{\prime}$ & 5930 & 6.0 & 5 & 181 & & $(0.87)$ & 158 \\
\hline $9 \mathrm{C}$ & $23^{\circ} 45.4^{\prime}$ & $60^{\circ} 02.9^{\prime}$ & 5922 & 5.0 & 5 & 263 & & $(0.87)$ & 229 \\
\hline 9D & $23^{\circ} 45.4^{\prime}$ & $60^{\circ} 02.9^{\prime}$ & 5922 & 6.0 & 6 & 391 & & $(0.87)$ & 340 \\
\hline $9 E$ & $23^{\circ} 45.4^{\prime}$ & $60^{\circ} 02.8^{\prime}$ & 5920 & 3.5 & 2 & 874 & & $(0.87)$ & 760 \\
\hline $9 \bar{F}$ & $23^{\circ} 45.4^{\prime}$ & $60^{\circ} 02.8^{\prime}$ & 5922 & 6.0 & 6 & 220 & & $(0.87)$ & 191 \\
\hline $9 G$ & $23^{\circ} 45.4^{\prime}$ & $60^{\circ} 02.8^{\prime}$ & 5924 & 6.0 & 6 & 126 & & (0.87) & 110 \\
\hline $9 \mathrm{H}$ & $23^{\circ} 45.4^{\prime}$ & $60^{\circ} 02.8^{\prime}$ & 5930 & 6.0 & 5 & 105 & & $(0.87)$ & 91 \\
\hline 9I & $23^{\circ} 45.4^{\prime}$ & $60^{\circ} 02.7^{\prime}$ & 5932 & 6.0 & 5 & 84 & & $(0.87)$ & 73 \\
\hline $9 \mathrm{~J}$ & $23^{\circ} 45.4^{\prime}$ & $60^{\circ} 02.7^{\prime}$ & 5933 & 6.0 & 5 & 69 & & (0.89) & 61 \\
\hline $9 K$ & $23^{\circ} 45.4^{\prime}$ & $60^{\circ} 02.6^{\prime}$ & 5933 & 6.0 & 5 & 69 & & $(0.89)$ & 61 \\
\hline $9 \mathrm{~L}$ & $23^{\circ} 45.4^{\prime}$ & $60^{\circ} 02.6^{\prime}$ & 5933 & 6.0 & 6 & 72 & & $(0.89)$ & 64 \\
\hline $9 \mathrm{M}$ & $23^{\circ} 45.4^{\prime}$ & $60^{\circ} 01.4^{\prime}$ & 5933 & 6.0 & 6 & 55 & & $(0.89)$ & 49 \\
\hline \multicolumn{10}{|l|}{ DHF } \\
\hline $10 \mathrm{~A}$ & $23^{\circ} 47.3^{\prime}$ & $59^{\circ} 52.9^{\prime}$ & 5933 & 6.0 & 5 & 65 & & $(0.89)$ & 58 \\
\hline $10 B$ & $23^{\circ} 47.1^{\prime}$ & $59^{\circ} 52.8^{\prime}$ & 5933 & 6.0 & 6 & 66 & & $(0.89)$ & 59 \\
\hline $10 C$ & $23^{\circ} 47.0^{\prime}$ & $59^{\circ} 52.8^{\prime}$ & 5933 & 6.0 & 5 & 70 & & $(0.89)$ & 62 \\
\hline $10 \mathrm{D}$ & $23^{\circ} 46.8^{\prime}$ & $59^{\circ} 52.8^{\prime}$ & 5933 & 6.0 & 6 & 77 & & $(0.89)$ & 68 \\
\hline $10 \mathrm{E}$ & $23^{\circ} 46.6^{\prime}$ & $59^{\circ} 52.7^{\prime}$ & 5933 & 6.0 & 6 & 79 & & $(0.89)$ & 70 \\
\hline $10 F$ & $23^{\circ} 46.5^{\prime}$ & $59^{\circ} 52.7^{\prime}$ & 5933 & 6.0 & 6 & 66 & & $(0.89)$ & 59 \\
\hline $10 G$ & $23^{\circ} 46.4^{\prime}$ & $59^{\circ} 52.6^{\prime}$ & 5933 & 6.0 & 6 & 61 & & $(0.89)$ & 54 \\
\hline $10 \mathrm{H}$ & $23^{\circ} 46.2^{\prime}$ & $59^{\circ} 52.6^{\prime}$ & 5933 & 6.0 & 6 & 63 & & $(0.89)$ & 56 \\
\hline $10 \mathrm{I}$ & $23^{\circ} 46.1^{\prime}$ & $59^{\circ} 52.6^{\prime}$ & 5933 & 6.0 & 5 & 58 & & $(0.89)$ & 52 \\
\hline $10 \mathrm{~J}$ & $23^{\circ} 46.0^{\prime}$ & $59^{\circ} 52.6^{\prime}$ & 5933 & 6.0 & 5 & 59 & & $(0.89)$ & 52 \\
\hline \multicolumn{10}{|l|}{ DHF } \\
\hline $11 \mathrm{~A}$ & $23^{\circ} 34.2^{\prime}$ & $60^{\circ} 06.7^{\prime}$ & 5932 & 6.0 & 6 & 64 & & $(0.89)$ & 57 \\
\hline $11 \mathrm{~B}$ & $23^{\circ} 34.1^{\prime}$ & $60^{\circ} 07.0^{\prime}$ & 5932 & 6.0 & 5 & 58 & & $(0.89)$ & 52 \\
\hline $11 \mathrm{C}$ & $23^{\circ} 340^{\prime}$ & $60^{\circ} 07.3^{\prime}$ & 5932 & 6.0 & 5 & 54 & & $(0.89)$ & 48 \\
\hline 11D & $23^{\circ} 33.9^{\prime}$ & $60^{\circ} 07.8^{\prime}$ & 5932 & 6.0 & 5 & 57 & & $(0.89)$ & 51 \\
\hline $11 \mathrm{E}$ & $23^{\circ} 33.8^{\prime}$ & $60^{\circ} 08.5^{\prime}$ & 5932 & 6.0 & 5 & 57 & & $(0.89)$ & 51 \\
\hline $11 F$ & $23^{\circ} 33.8^{\prime}$ & $60^{\circ} 09.3^{\prime}$ & 5932 & 6.0 & 5 & 63 & & $(0.89)$ & 56 \\
\hline $11 G$ & $23^{\circ} 33.6^{\prime}$ & $60^{\circ} 09.8^{\prime}$ & 5932 & 5.5 & 4 & $104 \pm 14$ & & $(0.89)$ & $93 \pm 12$ \\
\hline $11 \mathrm{H}$ & $23^{\circ} 33.7^{\prime}$ & $60^{\circ} 10.0^{\prime}$ & 5880 & 5.0 & 4 & $69 \pm 9$ & & (1.01) & $70 \pm 9$ \\
\hline $11 I$ & $23^{\circ} 33.6^{\prime}$ & $60^{\circ} 10.2^{\prime}$ & 5864 & 5.0 & 4 & $48 \pm 6$ & & (1.01) & $48 \pm 6$ \\
\hline $11 \mathrm{~J}$ & $23^{\circ} 33.5^{\prime}$ & $60^{\circ} 10.5^{\prime}$ & 5876 & 5.0 & 4 & $78 \pm 10$ & & (1.01) & $79 \pm 10$ \\
\hline $11 \mathrm{~K}$ & $23^{\circ} 33.4^{\prime}$ & $60^{\circ} 10.8^{\prime}$ & 5906 & 5.5 & 5 & $76 \pm 9$ & & $(1.01)$ & $77 \pm 9$ \\
\hline $11 \mathrm{~L}$ & $23^{\circ} 33.3^{\prime}$ & $60^{\circ} 10.9^{\prime}$ & 5932 & 5.5 & 5 & 63 & & $(0.89)$ & 56 \\
\hline \multicolumn{10}{|l|}{ DHF } \\
\hline $12 \mathrm{~A}$ & $23^{\circ} 38.5^{\prime}$ & $58^{\circ} 55.3^{\prime}$ & 6233 & 5.0 & 5 & $74 \pm 10$ & & $(0.90)$ & $66 \pm$ \\
\hline 12B & $23^{\circ} 38.4^{\prime}$ & $58^{\circ} 55.7^{\prime}$ & 6229 & 5.0 & 5 & $80 \pm 10$ & & $(0.90)$ & $72 \pm 9$ \\
\hline $12 \mathrm{C}$ & $23^{\circ} 38.3^{\prime}$ & $58^{\circ} 56.2^{\prime}$ & 6221 & 5.0 & 5 & $99 \pm 13$ & & $(0.90)$ & $89 \pm 12$ \\
\hline $12 \mathrm{D}$ & $23^{\circ} 38.2^{\prime}$ & $58^{\circ} 56.6^{\prime}$ & 6209 & 5.0 & 5 & 62 & & $(0.90)$ & 56 \\
\hline Bounce & $23^{\circ} 38.1^{\prime}$ & $58^{\circ} 57.0^{\prime}$ & 6176 & & & & & & \\
\hline $12 \mathrm{E}$ & $23^{\circ} 38.0^{\prime}$ & $58^{\circ} 57.4^{\prime}$ & 6140 & 5.0 & 5 & 63 & & $(0.90)$ & 57 \\
\hline $12 \mathrm{~F}$ & $23^{\circ} 37.9^{\prime}$ & $58^{\circ} 57.7^{\prime}$ & 6030 & 5.0 & 5 & $70 \mathrm{NL}$ & & $(0.90)$ & 63 \\
\hline $12 \mathrm{G}$ & $23^{\circ} 38.0^{\prime}$ & $58^{\circ} 58.1^{\prime}$ & 5940 & 5.0 & 5 & 80 & & $(0.90)$ & 72 \\
\hline Bounce & $23^{\circ} 38.0^{\prime}$ & $58^{\circ} 58.5^{\prime}$ & 5920 & & & & & & \\
\hline $12 \mathrm{H}$ & $23^{\circ} 38.0^{\prime}$ & $58^{\circ} 58.7^{\prime}$ & 5908 & 5.0 & 4 & $68 \pm 9$ & & $(0.90)$ & $61 \pm 8$ \\
\hline $12 I$ & $23^{\circ} 38.0^{\prime}$ & $58^{\circ} 59.0^{\prime}$ & 5910 & 5.0 & 5 & $\overline{54}$ & & $(0.90)$ & 49 \\
\hline $12 \mathrm{~J}$ & $23^{\circ} 38.0^{\prime}$ & $58^{\circ} 59.2^{\prime}$ & 5908 & 5.0 & 4 & 54 & & $(0.90)$ & 49 \\
\hline $12 \mathrm{~K}$ & $23^{\circ} 38.0^{\prime}$ & $58^{\circ} 59.5^{\prime}$ & 5894 & 5.0 & 5 & 57 & & $(0.90)$ & 51 \\
\hline \multicolumn{10}{|l|}{ DHF } \\
\hline $13 \mathrm{~A}$ & $23^{\circ} 42.2^{\prime}$ & $60^{\circ} 07.4^{\prime}$ & 5933 & 5.0 & 5 & $72 \pm 9$ & & $(0.89)$ & $64 \pm 8$ \\
\hline $13 B$ & $23^{\circ} 42.6^{\prime}$ & $60^{\circ} 07.9^{\prime}$ & 5933 & 5.0 & 5 & 43 & & $(0.89)$ & $\overline{38}$ \\
\hline $13 \mathrm{C}$ & $23^{\circ} 42.4^{\prime}$ & $60^{\circ} 08.1^{\prime}$ & 5933 & 5.0 & 5 & 50 & & $(0.89)$ & 44 \\
\hline 13D & $23^{\circ} 42.0^{\prime}$ & $60^{\circ} 08.6^{\prime}$ & 5861 & 5.5 & 6 & 102 & & (1.01) & 103 \\
\hline $13 \mathrm{E}$ & $23^{\circ} 41.8^{\prime}$ & $60^{\circ} 08.8^{\prime}$ & 5836 & 5.0 & 5 & $77 \pm 10$ & & (1.01) & $78 \pm 10$ \\
\hline $13 F$ & $23^{\circ} 41.7^{\prime}$ & $60^{\circ} 09.0^{\prime}$ & 5830 & 5.0 & 5 & 79 & & (1.01) & 80 \\
\hline $13 G$ & $23^{\circ} 41.6^{\prime}$ & $60^{\circ} 09.2^{\prime}$ & 5834 & 5.0 & 5 & 66 & & (1.01) & 67 \\
\hline $13 \mathrm{H}$ & $23^{\circ} 41.4^{\prime}$ & $60^{\circ} 09.4^{\prime}$ & 5836 & 5.0 & 5 & 72 & & (1.01) & 73 \\
\hline $13 \mathrm{I}$ & $23^{\circ} 41.3^{\prime}$ & $60^{\circ} 09.5^{\prime}$ & 5838 & 5.0 & 5 & 124 & & (1.01) & 125 \\
\hline $13 \mathrm{~J}$ & $23^{\circ} 41.1^{\prime}$ & $60^{\circ} 09.7^{\prime}$ & 5838 & 5.0 & 5 & $104 \pm 14$ & & (1.01) & $105 \pm 14$ \\
\hline $13 K$ & $23^{\circ} 41.0^{\prime}$ & $60^{\circ} 09.8^{\prime}$ & 5836 & 5.0 & 4 & $58 \pm 8$ & & $(1.01)$ & $58 \pm 8$ \\
\hline $13 \mathrm{~L}$ & $23^{\circ} 40.9^{\prime}$ & $60^{\circ} 10.0^{\prime}$ & 5836 & 5.0 & 4 & 43 & & (1.01) & 43 \\
\hline TG 1 & $23^{\circ} 46.2^{\prime}$ & $60^{\circ} 02.2^{\prime}$ & 5932 & 10.8 & & & 10 & 0.928 & \\
\hline TG 2 & $23^{\circ} 46.6^{\prime}$ & $59^{\circ} 52.5^{\prime}$ & 5937 & 12.6 & 4 & & 59 & 0.923 & \\
\hline TG 3 & $23^{\circ} 46.6^{\prime}$ & $59^{\circ} 52.9^{\prime}$ & 5890 & 5.5 & & & 25 & 0.871 & \\
\hline TG 4 & $23^{\circ} 34.6^{\prime}$ & $60^{\circ} 05.4^{\prime}$ & 5877 & 12.2 & 5 & & 11 & 0.954 & \\
\hline TG 5 & $23^{\circ} 40.3^{\prime}$ & $58^{\circ} 52.8^{\prime}$ & 6233 & 10.7 & 3 & & 15 & 0.924 & \\
\hline
\end{tabular}

Penetration is the penetration depth of probe; $N_{p}$ is the number of probes in mud. GRD is thermal gradient. $N_{K}$ is the number of conductivity measurements in core, and $K$ is the thermal conductivity mean for either measurements at that station or, if parenthetical, the closest station. $Q$ is the heat flow. Error bars are indicated if tilt switch indicated 8-30 tilt. 

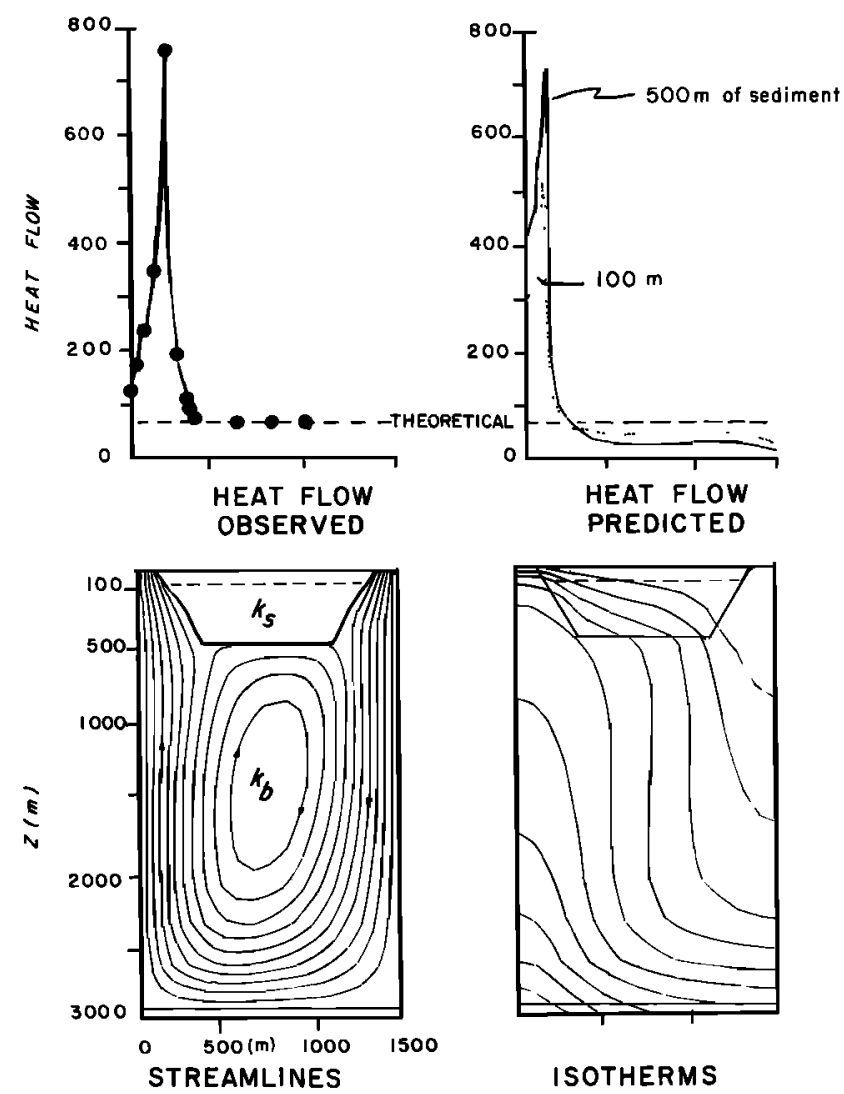

Fig. 7. (bottom) Streamlines (left) and isotherms of hydrothermal convection assuming $300 \mathrm{~m}$ of sediment (permeability $10^{-13}$ $\mathrm{cm}^{2}$ ) between basement outcrops (permeability $10^{-10} \mathrm{~cm}^{2}$ ). (top) Heat flow anomaly calculated from model compared to anomaly measured across dome (inset, profile 9).

With the exception of DHF profile 9, all of the profiles show consistent patterns. Over the flat abyssal plain the values are very constant (Figure 5) and the mean of $57 \mathrm{~mW}$ $\mathrm{m}^{-2}(1.3 \mathrm{HFU})$ agrees precisely with the value predicted for this age crust from the cooling plate model (Figure 3). Over the abyssal hills the values vary in a cyclic manner (Figure 5) with a maximum peak to peak variation of $83 \mathrm{~mW} \mathrm{~m}$ (profile 13). The wavelength of the cycles is $1.0-2.0 \mathrm{~km}$ on profiles 11 and 12 and about $2.5-3.0 \mathrm{~km}$ on profile 13 . The mean heat flow over the hills in the survey area is $77 \mathrm{~mW}$ $\mathrm{m}^{-2}$, which is $37 \%$ above the mean of the abyssal plain.

The anomaly over the dome (Profile 9) is $710 \mathrm{~mW} \mathrm{~m}^{-2}$ peak to trough. From the onboard pinger record the anomaly peak is at the crest of the dome structures. Indications from the pinger records made during the heat flow station and other records made over similar domes (Figure 2) indicate that the sediment is only about $10-20 \mathrm{~m}$ thick on the tops of the domes.

\section{Dome Structures}

The prime goal of the cruise was to determine the nature of the unusual dome structures. Because of the lack of transponder navigation, the small size of the features, and the deep water only one core from the domes was obtained (RC21-14) (Figure 6). This dome is roughly circular in shape, and approximately $1.0 \mathrm{~km}$ in diameter where it intersects the seabed. It rises about $50 \mathrm{~m}$ above the abyssal plain with slopes of 10-20.

The core (RC20-14) was $610 \mathrm{~cm}$ long and obviously stopped in a hard substratum, as the coring tube was bent in the middle at a $30^{\circ}$ angle. The top section of the core (Figure 6) consists of $410 \mathrm{~cm}$ of typical brown pelagic clay with five thin $(3-10 \mathrm{~cm})$ gray silt/clay turbidites. The bottom section consists of orange-pink clay with embedded fragments of manganese and highly altered basalt near the bottom (610 $\mathrm{cm})$. An $X$ ray diffraction analysis (E. Bonatti, personal communication, 1981) of the clay shows that it consists primarily of phillipsite and polygorskite (the latter also known as attapulgite). Phillipsite is an alteration product produced by basalt-sea water reactions. Its presence is consistent with the long-term exposure of the dome to sea water. Polygorskite is most commonly found in fresh water, lagoons [Kerr, 1937; Heysteck and Schmidt, 1953], and in shallow marine environments [Muller, 1961], but it has also been described as an alteration product of basalt [Stephen. 1954]. Bonati and Joensuu [1968] has described an occurrence of polygorskite in a sample from the western Atlantic and concludes that it was formed by hydrothermal fluids interacting with montmorillonite. Polygorskite has also been described in DSDP and IPOD cores [e.g., Mann and Muller, 1979; Zemmels et al., 1972].

\section{Discussion}

Regional heat flow studies (Figure 3) have shown that Atlantic sea floor of the age of the study area is in transition from convective to conductive heat transfer. Anderson et al. [1979] have discussed two types of convective heat transfer: that directly from rock outcrops into water (Type 1) and that from basement into water via sediments (Type 2). Type 2 heat transfer is characterized by nonlinear temperature gradients [Anderson et al., 1979]. Since no nonlinear gradients were measured during the Nares survey, we conclude that Type 2 heat transfer is not common in this area. Furthermore, measured values in the abyssal plain correspond to the heat flow from the cooling plate mode. However, measurements over the abyssal hills, where the sediment is about $50 \%$ thinner, show a cyclical pattern of the heat flow with peak to trough variation of $20-80 \mathrm{~mW} \mathrm{~m}^{-2}$ and a mean value $37 \%$ higher than that of the abyssal plain. Station 12 , taken $100 \mathrm{~km}$ east, has a mean value of about $10 \%$ higher than that predicted by the cooling plate model. The conclusion is that this crust is being warmed by upwelling water which has entered elsewhere. Stations 11 and 3 are on the same abyssal hill lineament, which may be a discharge area. Unfortunately, we have no data from other ridges in the area to verify this. Possible mechanisms for the very high heat flow anomaly over the dome structure include: (1) refractive conduction, (2) topographically driven subcritical hydrothermal convection, (3) recent volcanic intrusion, and (4) hydrothermal dischage from a chimney of high permeability rock (the dome).

Since the maximum effect of refraction is about $40 \%$ [Lachenbruch, 1968] and the Nares anomaly is a factor of 15 greater than the regional mean, this cannot be the mechanism. Similarly, the maximum deviation due to topographically driven subcritical hydrothermal convection is about $15 \%$ [Lowell, 1980], so this is also too small an effect to explain the Nares anomaly.

The third hypothesis, that the dome is a much more recent intrusive, could explain the anomaly. The thin sediment cover observed on one of the domes is consistent with this explanation. Although this explanation cannot be ruled out, 
there is no obvious regional tectonic framework into which a very young intrusion might fit.

The final possibility is an active (supercritical hydrothermal) convection system. There has been very little data on whether or not such convection exists in old crust. It is now clear that thick sediment effectively seals off any such convection in old crust from the ocean over much of the world's oceans [McDuff, 1981]. Some workers [e.g., Houtz and Ewing, 1976] have also suggested that mineralization in the upper crust seals off cracks, thus effectively stopping the convection. However, Anderson et al. [1977, 1979] have shown that active hydrothermal convection can still exist on crust as old as $55 \mathrm{~m} . \mathrm{y}$. and that sediment cover, with or without mineralization, is the dominant factor in sealing off the near-surface hydrothermal system from exchange with the ocean.

To test whether the anomaly could be explained by supercritical hypothermal convection, a finite element porous media convection model was developed (Figure 7). Details of the model are given by Gartling and Anderson [this issue] and Anderson and Gartling [this issue]. The model consists of a $10^{-10} \mathrm{~cm}^{2}$, highly permeable rock outcropping every $1.8 \mathrm{~km}$ at the sea floor separated by a variable thickness of low-permeability sediment $\left(10^{-13} \mathrm{~cm}^{2}\right)$. There is a uniform heat flux of $57 \mathrm{~mW} \mathrm{~m}^{-2}$ into the bottom of the model $3 \mathrm{~km}$ below the surface. Convection concentrates discharge and recharge at the outcrops, and the surface heat flow is greatly changed from the conduction case. The model predicts that the thicker the sediment ponded between outcrops, the higher the heat flow 'spike' at the upwelling 'chimney' (Figure 7).

The model matches the observed heat flow anomaly for sediment $500 \mathrm{~m}$ thick; this is slightly greater than the actual $300 \mathrm{~m}$. If, indeed, such models successfully duplicate the sea floor convection system, they provide a significant insight into how sealing proceeds in the oceans. At the ridge axis where convection from the crust to the ocean is unimpeded by sediments, low heat flow is measured in most small sediment ponds, since the heat flux outward is channelled elsewhere. As the sedimentation continues away from the ridge axis, however, fewer and fewer 'chimneys' are left uncovered by the accumulating, impermeable blanket of mud, yet the heat flux out of these chimneys actually is predicted to increase with age until the last few have very high heat flow (as in our case). Eventually, these too are sealed up, and the heat flow drops to that predicted by conductive cooling lithospheric plate models.

There remain some questions as to the validity of these conclusions. For example, where are the recharge areas, over what horizontal distances do such systems operate, and what is the explanation for the anomalously thin sediment cover over the dome? When looking at the last question, if the dome core actually stopped in or near the rock-sediment interface, and if the subbottom reflector (Figure 2) represents the top of layer 2 , then the sediment over the dome is only 6-10 m thick, an order of magnitude less than the normal abyssal hill cover for the area. To explain this, one has to invoke (1) mass wasting of sediment from the top of the dome, (2) a process which has preferentially kept the crest of the dome sediment free for most of its life, and/or (3) a significantly younger age for the dome versus the abyssal hills. Without more substantial evidence in favor of 3 , we will use either 1 or 2 as a working hypothesis. Mass wasting is relatively common on small abyssal hills of the Pacific (J. Damuth, personal communication, 1981). Furthermore, two of the abyssal plain cores (RC20-12, 13) contain layers which could be interpreted as locally redeposited material. On the other hand there is no indication of a hiatus in the core, so the thinner section could be due to preferential deposition as a result of bottom currents. Moore and Heath [1967] found that sediment thickness varied by a factor of four on abyssal hills in the central Pacific. Luyendyk [1970], Rona et al. [1974], and Mudie et al. [1972] also found significant perferential thinning of sediment cover over crests of abyssal hills. Purdy et al. [1980] found that the sediment cover over the basement hill drilled into on DSDP Site 417A is only half that of the surrounding seabed. Thus a reasonable explanation of the very thin sediment cover over the dome is either mass wasting or bottom currents. Another suggestion is that during much of its history the dome was emanating warm water at a rate which tended to retard deposition of pelagic sediment in some manner.

The domes are best described as circular or near-cylindrical features with about $150-200 \mathrm{~m}$ of relief, a base diameter of approximately $2-3 \mathrm{~km}$, and slopes of $10^{\circ}-20^{\circ}$. Since the top appears to be level, at least on one portion (Figure 2), the domes have the apparent morphology of a small volcano. Similar features have been observed in other abyssal hill areas. Luyendyk [1970] described 'conical knobs' in the Pacific which have a size and morphology similar to the Nares domes and concluded that they are extinct volcanoes. Volcanoes of this size have been described and/or mapped in the crestal areas of several spreading centers [e.g., Renard et al., 1975; Allmendinger and Riss, 1979].

It may be that the small basement hill of DSDP site $417 \mathrm{~A}$ is an older analogue ( $100 \mathrm{~m}$.y. B.P.) to the domes of the eastern Nares plain. The $417 \mathrm{~A}$ hill is steep walled $(20-40)$, flat topped, and of a similar size [Purdy et al., 1980]. It, too, was apparently altered by hydrothermal fluids circulating within it [Donnelly et al., 1980]. The alteration at this site was much more intense than through the rocks at site 417D which was drilled only $400 \mathrm{~m}$ away. However, measurements in the region around the drill sites have not detected anomalous heat flow [Galson and Von Herzen, 1981].

Acknowledgments. We thank the crew and scientific party of the R/V Conrad, particularly G. Bryan, D. Roach, and P. Hoose, for valuable assistance in the field. We also gratefully acknowledge $\mathrm{E}$. Bonatti for performing X ray diffraction on core RC21-14. Data collection and analysis were supported by Office of Naval Research contract N00014-75-C-0210 to Lamont-Doherty Geological Observatory. This is Lamont-Doherty Geological Observatory contribution number 3401.

\section{REFERENCES}

Abbott, D., and R. Embley, Upslope flow of turbidity currents onto Abyssal hills in eastern Nares abyssal Plain, Eos Trans. AGU, 63, 445, 1982.

Allmendinger, R. W. and F. Riis, The Galapagos Rift at $86^{\circ} \mathrm{W}, 1$, Regional morphological and structural analysis, J. Geophys. Res., $84,5379-5389,1979$

Anderson, R. N., and D. K. Gartling, Finite element analysis of geothermal convection in the oceanic crust and overlying sediment, 2, Layers with variable topography, J. Geophys. Res., this issue.

Anderson, R. N., and M. A. Hobart, The relation between heat flow, sediment thickness and age in the eastern Pacific, $J$. Geophys. Res., 81, 2968-2996. 1976.

Anderson, R. N., and J. G. Skilbeck, Oceanic heat flow, in The Sea, 
vol. 7, The Oceanic Lithosphere, edited by C. Emiliani, pp. 489523, John Wiley, New York, 1982.

Anderson, R. N., M. G. Langseth, and G. Sclater, The mechanisms of heat transfer through the floor of the Indian Ocean, J. Geophys. Res., 82, 3391-3409, 1977.

Anderson, R. N., M. A. Hobart, and M. G. Langseth, Geothermal convection through oceanic crust and sediments in the oceanic crust, Science, 204, 828-832, 1979.

Bonatti, E., and D. Joensuu, Palygorskite from Atlantic deep sea sediments, Am. Mineral., 53, 975-983, 1968.

Corliss, J. B., J. Dynmond, L. I. Gordon, J. M. Edmond, R. P. von Herzen, R. D. Ballard, K. Green, D. Williams, A. Bainbridge, K. Crane, and T. H. van Andel, Submarine thermal springs on the Galapagos Rift, Science, 203, 1073-1083, 1979.

Donnelly, T., et al., Init. Rep. Deep Sea Drilling Proj., 51-53, 1980.

Galson, D. A., and R. P. Von Herzen, A heat flow survey on anomaly MO south of the Bermuda Rise, Earth Planet. Sci. Lett., 53, 296-306, 1981.

Gartling, D. H., and R. N. Anderson, Finite elements models of geothermal convection in the ocean crust, J. Geophys. Res., this issue.

Heysteck, H., and E. R. Schmidt, The mineralogy of the attapulgitemontmorillonite deposit in the Springbok Flats Transvaal, Trans. Geol. Soc. S. Afr., 56, 99-119, 1953.

Houtz, R., and J. I. Ewing, Upper crustal structure as a function of plate age, J. Geophys. Res., 81, 2490-2498, 1976.

Kerr, P. F., Attapulgus clay, Am. Mineral., 22, 534-540, 1937.

Lachenbruch, A. H., Rapid estimation of the topographic disturbance to superficial thermal gradients, Rev. Geophys., 6, 365$400,1968$.

Larson, R. L., and W. C. Pitman III, World-wide correlation of Mesozoic magnetic anomalies and their implication, Geol. Soc. Am. Bull., 83, 3645-3662, 1972.

Lister, C. R. B., On the thermal balance of a mid-ocean ridge, $Q . J$. $R$. Astron. Soc., 26, 515-535, 1971.

Lowell, R. P., Topographically driven subcritical hydrothermal convection in the oceanic crust, Earth Planet. Sci. Lett., 49, 21$28,1980$.

Luyendyk, B. P., Origin and history of abyssal hills in the northeast Pacific Ocean, Geol. Soc. Am. Bull., 81, 2237-2260, 1970.

Mann, J., and G. Muller, X-ray mineralogy of deep-sea drilling project legs 51 through 53, Western North Atlantic, Init. Rep. Deep Sea Drilling Proj., 51-53, part 2, 1979.

McDuff, R. E., Major cation gradients in DSDP interstitial waters: the role of diffusive exchange between seawater and upper oceanic crust, Geochim. Cosmochim. Acta, 45, 1705-1713, 1981.

Moore, T. C., and G. R. Heath, Abyssal hills in the central equatorial Pacific: detailed structure of the sea floor and subbottom reflectors, Mar. Geol., 5, 161-179, 1967.

Mudie, J. D., J. A. Grow, and J. S. Bessey, A near-bottom survey of lineated abyssal hills in the equatorial Pacific, Mar. Geophys. Res., I, 397-441, 1972.

Muller, G., Palygorskit and sepiolith in tertiaren and quartaren sedimenten von hadramaut (S. Arabian), Neues Jahrb. Mineral. $A b h .$, 97, 275-288, 1961.

Pitman, W. C., III, and M. Talwani, Sea-floor spreading in the North Atlantic, Geol. Soc. Am. Bull., 83, 619-646, 1972.

Purdy, G. M., J. I. Ewing, and G. M. Bryan, A deep-towed hydrophone seismic-reflection survey around IPOD sites 417 and 418, Mar. Geol., 35, 1-19, 1980.

Rabinowitz, P. D., and W. J. Ludwig, Geophysical measurements at candidate drill sites along an east-west flow line in the central Atlantic Ocean, Mar. Geol., 35, 243-275, 1980.

Renard, V., B. Schrumpf, J. C. Sibuet, and D. Carre, Bathymetrique detaillee d'une partie devallee du rift et de faille transformante pres de $35^{\circ} \mathrm{W}, 50^{\circ} \mathrm{N}$ dans l'ocean Atlantique, report, Centre Natl. pour l'Expolit. des Oceans, Paris, 1975.

RISE Project Group, East Pacific Rise: Hot springs and geophysical experiments, Science, 207, 1421-1433, 1980.

Rona, P. A., R. N. Harbison, and S. A. Bush, Abyssal hills of the eastern central North Atlantic, Mar. Geol., 26, 275-292, 1974.

Stephen, I., An occurrence of palygorskite in the Shetland Isles, Mineral. Mag., 30, 471-480, 1954.

Talwani, M., C. C. Windisch, and M. G. Langseth, Reykjanes ridge crest: a detailed geophysical study, J. Geophys. Res., 76, 473517, 1971 .

Tucholke, B. E., Acoustic environment of the Hatteras and Nares abyssal plains, western North Atlantic Ocean, determined from velocities and physical properties of sediment cores, J. Acoust. Soc. Am., 68, 1376-1390, 1980.

Tucholke, B. E., and G. S. Mountain, Seismic stratigraphy in lithostratigraphy and paleosedimentation patterns in the North American Basin, in Deep Drilling Results in the Atlantic Ocean: Continental Margins and Paleo-Environment, Maurice Ewing Ser., vol. 3, edited by M. Talwani, W. Hay and W. B. F. Ryan, pp. 58-86, AGU, Washington, D. C., 1979.

Zemmels, I., H. E. Cook, and J. C. Hathaway, X-ray mineralogy studies-Leg XI, Init. Rep. Deep Sea Drilling Proj., 11, 721-790, 1972.
(Received October 30, 1981; revised June 23, 1982; accepted September 7, 1982.) 